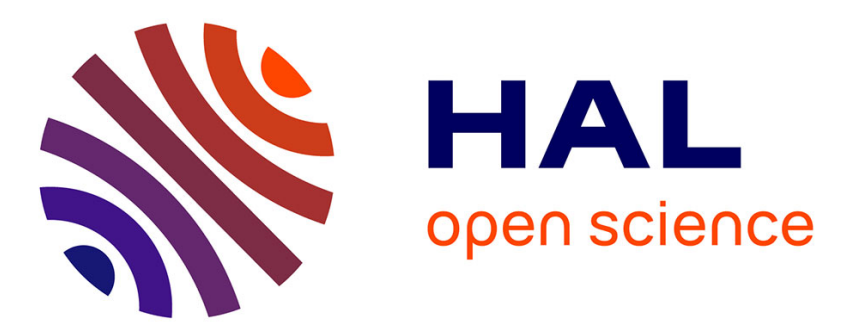

\title{
Legitimacy of consumer associations and perceived vulnerability of their users: Effects on intentions to trust consumerist associations
}

Marie-Christine Lichtlé, Lydiane Nabec, Dominique Roux, Corinne Chevalier

\section{- To cite this version:}

Marie-Christine Lichtlé, Lydiane Nabec, Dominique Roux, Corinne Chevalier. Legitimacy of consumer associations and perceived vulnerability of their users: Effects on intentions to trust consumerist associations. Recherche et Applications en Marketing (English Edition), 2018, 33 (1), pp.5372. $10.1177 / 2051570718756553$. hal-02022174

\section{HAL Id: hal-02022174 \\ https://hal.science/hal-02022174}

Submitted on 15 Jul 2021

HAL is a multi-disciplinary open access archive for the deposit and dissemination of scientific research documents, whether they are published or not. The documents may come from teaching and research institutions in France or abroad, or from public or private research centers.
L'archive ouverte pluridisciplinaire HAL, est destinée au dépôt et à la diffusion de documents scientifiques de niveau recherche, publiés ou non, émanant des établissements d'enseignement et de recherche français ou étrangers, des laboratoires publics ou privés. 


\title{
LEGITIMACY OF CONSUMER ASSOCIATIONS AND PERCEIVED VULNERABILITY OF THEIR USERS: EFFECTS ON INTENTIONS TO TRUST CONSUMERIST ASSOCIATIONS
}

\author{
Marie-Christine LICHTLE \\ Professeure des Universités, Université de Montpellier, Laboratoire MRM \\ Université de Montpellier \\ Institut Montpellier Management \\ MRM \\ Espace Richter \\ Avenue Raymond Dugrand \\ 34960 Montpellier cedex 2 \\ E-mail : Marie-Christine.Lichtle@umontpellier.fr
}

Lydiane NABEC

Maître de Conférences HDR, Université de Paris-Sud/Paris-Saclay, Laboratoire RITM

54 Boulevard Desgranges

92331 Sceaux Cedex

E-mail : lydiane.nabec@u-psud.fr

Dominique ROUX

Professeure des Universités, Université de Reims Champagne-Ardenne, Laboratoire REGARDS

Université de Reims Champagne-Ardenne

UFR des Sciences Economiques, Sociales et de Gestion, Laboratoire Regards,

Bâtiment Recherche, 57 bis rue Pierre Taittinger, 51096 Reims cedex

E-mail : dominique.roux@univ-reims.fr

\section{Corinne CHEVALIER}

Maître de Conférences, Université de Paris-Sud/Paris-Saclay, Laboratoire RITM

Université de Paris-Sud - IUT

8 Avenue Cauchy

92330 Sceaux

E-mail : corinne.chevalier@u-psud.fr

- To quote this article: Lichtlé M.-C., Nabec L., Roux D. et Chevalier C. (2018), Legitimacy of consumer associations and perceived vulnerability of their users: Effects on intentions to trust consumerist associations, Recherche et Applications en Marketing (English Edition), 33(1): 53-72. 


\begin{abstract}
The trust that people place in consumer associations to protect their interests in dealing with commercial entities is at the heart of the consumerist mission. It is therefore important to identify the factors underpinning this trust. The results of one qualitative study (51 respondents) and one quantitative study (315 individuals) reveal that intentions to trust a consumer association depend on its recognised degree of cognitive, pragmatic and moral legitimacy. Furthermore, the effect of pragmatic legitimacy on such intentions varies in accordance with the perceived vulnerability of consumers in dealing with commercial entities. However, perceived vulnerability does not moderate the relationship between cognitive and moral legitimacy and intentions to trust consumer associations: it has a direct influence on this response variable.
\end{abstract}

\title{
Keywords
}

Consumer associations, trust, consumerism, legitimacy, vulnerability. 


\section{Introduction}

Consumer rights movements have been around as long as trade itself (Bihl-Willette, 1984; Fontaine, 2014), even though they only really became structured after World War II. The 1962 Consumer Bill of Rights in the United States guaranteed every citizen four basic rights: the right to safety, the right to be informed, the right to choose and the right to be heard (Buskirk and Rothe, 1970). Meanwhile France saw the creation of the cooperative movement (Gide, 1898/1931) and the Ligue sociale d'acheteurs (Chessel, 2012, 2016). Under the Marshall Plan, reconstruction led to the emergence of the main bodies representing and defending consumers (Chatriot, 2004). The oldest of these is the Union Fédérale de la Consommation (UFC), established in 1951 at the initiative of the "general commissariat for productivity", which it was created to serve (Pflieger, 2003). With the objective of "the protection of consumers from deceptive and misleading practices, dangerous products, monopolistic activities, and other marketing abuses" (Webster, 1973: 90), the consumerist mission developed as a way to represent consumers and as a means to make the post-war economy more dynamic and modern.

With six decades of activities and support from the State in the form of certification, financing and legislation ${ }^{1}$, the consumerist movement has become an institution, with a kind of "taken-for-grantedness" (Suchman, 1995: 582) whose persistence and solid foundations appear difficult to challenge. Yet despite its historic and institutionalised status, its legitimacy is beginning to be questioned. First of all, doubts have been raised about the neutrality of consumer associations due to the fact that some of them are ideologically oriented in political or religious terms. Furthermore, consumers worry that the comparative tests they carry out are financed by commercial players (Nabec et al., 2015). The "consumerist information market" is also saturated and it can be difficult to know who is communicating (Roux et al., 2015). As a result, consumers struggle to identify which sources are truly independent. For example, when they confuse a consumer association with a retail brand on the basis that the latter provides a price comparison service, the perceived legitimacy of such associations is undermined (Nabec et al., 2015). What is more, political, economic and health scandals have led to the widespread belief among consumers that the State is unable to protect their rights (Gabaix et al., 2012). Such a climate of confusion feeds into general feelings of suspicion that damage the trust placed in commercial businesses (Benedicktus et al., 2010; Darke et al., 2008), but also in organizations that work to support legitimate causes (Vestergaard, 2014), including consumer associations. 
This raises three questions, which echo reflections on improving consumer well-being (Gorge et al., 2015): are consumer associations still perceived as legitimate by their users? If so, and in light of the frequent lack of direct experience with these organizations ${ }^{2}$, does this perceived

legitimacy influence the intentions of these users to trust them? Finally, given that individuals have differing abilities to defend themselves (Chazal, 2000), what role does their perceived vulnerability play in this relationship? Although the ability of consumers to defend themselves collectively have been illustrated recently (Roux et al., 2015), what about the powerlessness of isolated individuals to resolve disputes on their own (Bourdieu and Pinto, 2013; Roux, 2012)? The law might assume that they are in a position of weakness when dealing with commercial parties, given that they are not professionals (Calais-Auloy and Steinmetz, 1996), but it is particularly important to analyse whether the most vulnerable consumers, based on their perceptions, are more likely to trust consumer associations. This paper therefore explores whether their feelings of vulnerability moderate the effect of the perceived legitimacy of these organizations on their intentions to trust them.

To address these questions, we begin by presenting our conceptual research framework, followed by a qualitative study and the hypotheses that emerge from it, before going on to describe the quantitative methodology used and the results obtained. To conclude, we identify theoretical and managerial implications and highlight the limitations of our research as well as future research avenues.

\section{The effects of an organization's legitimacy on people's intentions to trust it: theoretical framework}

Organizational legitimacy

Legitimacy is a notion first developed in political science and can be defined as the perception that the actions of an entity are proper or appropriate within a system of norms, values and beliefs (Suchman, 1995). It stems from a process of judgements and responses formed based on the nature of the activities, behaviour and values of this organization (Bitektine, 2011). At the scale of a company, it is the marketing actions it implements that will help make its offer legitimate, i.e. make it a part of shared schemas and meanings (Chaney and Ben Slimane, 2014).

Two types of judgement have been traditionally used to understand this concept (Bitektine, 2011; Suchman, 1995): cognitive legitimacy and sociopolitical legitimacy.

"Cognitive legitimacy" is based on evaluations of shared meaning that make certain organizations taken for granted, beyond question. This is not about assessing the merits of 
their activities but of appreciating the immediately comprehensible nature of their presence (Suchman, 1995). In this regard, certified consumer associations are legitimate in cognitive terms: they have existed for almost 70 years and the State authorises them to defend consumers (Laurent, 2009). This allows them to achieve what Meier and Scheier (2008) call elective legitimacy. However, if they seek recognition from people who no longer identify them (Roux et al., 2015), their cognitive legitimacy can be compromised.

"Sociopolitical legitimacy" relates to how individuals evaluate the benefits which some organizations offer based on their norms and values (Suchman, 1995). This means that, all else being equal, this form of legitimacy is highly dependent on the beliefs, attitudes, values or life experiences of the individuals concerned. According to Bitektine (2011), judgements about sociopolitical legitimacy can themselves be divided into two categories. First, egotropic judgements (or pragmatic legitimacy) are formed based on evaluations of the effectiveness and capacity of organizations to satisfy their audiences (Suchman, 1995). When applied to consumer associations, egotropic legitimacy is assessed in relation to the means they have at their disposal to inform and defend consumers (Laurent, 2009). When it comes to helping them to resolve disputes, Roux et al. (2015) show that they must be easily identifiable and accessible for consumers to call on their services. As well as accessibility, a broader question has been raised about their ability to resolve problems in operational and legal matters. With regard to the first issue, their effectiveness largely depends on the available financial resources with which to successfully complete their tasks. Such resources are increasingly scarce, reducing the capacity of organizations to "recruit and remunerate professionals" (Laurent, 2009: 14). On the second issue, the legislation on consumption in France, known as the "loi Hamon", now allows them to take group action and act to defend a collection of individual interests. However, bestowing this extended right on consumer associations also places a "real responsibility" on them, for in the absence of additional resources consumers could have cause to "criticise the organization, particularly in the case of inaction" (Azar-Baud, 2016: 198).

The second type, sociotropic judgements (or moral legitimacy), relates to the benefits that organizations can offer society as a whole (Suchman, 1995). These judgements are therefore above all based on the societal value associated with consumerism. The increased atomisation of the consumerist landscape undermines the visibility of consumer associations.

Furthermore, their number and the heterogeneity of the issues they pursue lead to possible confusion between certain categories of interests - supported by trade union-based organizations in particular - and the defence of consumer rights, which must play a 
"preponderant" role (Laurent, 2009: 28). In summary, the legitimacy of consumer associations stems from the judgements made about their institutional status (cognitive legitimacy), their perceived capacity for recognition and ability to be accessible and protect consumers (pragmatic legitimacy), and their contribution to the well-being of individuals, in particular those least able to inform and defend themselves (moral legitimacy). We therefore define the legitimacy of consumer associations as the "ability to be identified as natural agents of consumer protection, to deploy appropriate means for this protection, and to ensure collectively that this mission serves the most fragile people".

Legitimacy remains a specific concept despite its proximity to notions of fame, status or reputation. Fame, first of all, can be defined as attracting the attention of an audience and generating positive affects in them. This performance is not in itself discriminant when it comes to establishing organizational legitimacy (Rindova et al., 2006). Similarly, status and reputation do not rely on the same theoretical underpinnings - institutionalism - as legitimacy. In network theory, status is a measure of the evaluative qualities of an actor's position in relation to others. Reputation, under signalling theory, is based on performance indicators that point to an organization's capacity to produce value. Neither status nor reputation, therefore, is based on political criteria of acceptance and social relevance, in contrast to legitimacy (Bitektine, 2011).

\section{Trusting an organization and the role of legitimacy in forming intentions to trust}

Trust can be defined as a psychological state made up of accumulated beliefs, expectations and presumptions "with regard to the credibility, integrity and benevolence" of one's partner in an exchange in respect of their future behaviour (Gurviez and Korchia, 2002: 47).

Downstream of these beliefs, expectations and presumptions, it is a conative component manifested through an intention (to trust) or (trusting) behaviour (Chouk and Perrien, 2003; Guibert, 1999). As a psychological state, trust is therefore built on determinants of a cognitive (e.g. credibility and integrity) and affective nature (e.g. benevolence). These result in parties ascribing qualities of competence, honesty and willingness to one another for their mutual benefit and happiness (Morgan and Hunt, 1994). Similarly, research on institutional trust built up between an individual and a legal entity - retailer, manufacturer, State, consumer association - describe it as the "deliberate willingness to count on the reliability and benevolence of a party in whom one believes" (Benamour, 2000: 128).

In its conative dimension, trust reflects the intention or willingness of one party to have faith in the other (Moorman et al., 1992; Rotter, 1971). This trust can be strengthened by the 
positive outcome of prior professional relations (Bidault and Jarillo, 1995; Guibert, 1999; Mayer et al., 1995) or the quality of previous experiences with an organization (Bryce, 2007). These give its partners or members of the public better knowledge of its actions, which in turn feeds into their intentions to trust it.

With regard to consumption, research has revealed the mediating role of trust in the relationship between cumulative satisfaction and engagement, which subsequently has an influence on loyalty (Aurier et al., 2001; Cissé-Depardon and N'Goala, 2009; Gustafsson et al., 2005; Lichtlé and Plichon, 2008; Morgan and Hunt, 1994; Sirieix and Dubois, 1999). However, these research studies focus on consumer satisfaction and therefore necessarily presuppose the existence of prior experience. What if there is no such experience? Although it is impossible in such cases to consider satisfaction and therefore ex-post trust (Gurviez and Korchia, 2002), it is possible to anticipate intentions to engage in the relationship using variables other than satisfaction (Bartikowsky et al., 2007). This is because presumptions about the competence, honesty or capacity of a partner to take the interests of others into account $-a$ priori trust - can depend on other forms of available knowledge. This is what has been shown by research studies that do not directly measure individuals' trust in organizations but which explore it in terms of perceived legitimacy (Arnold et al., 1996; Handelman and Arnold, 1999). The more organizations are perceived as legitimate, the more consumers manifest favourable behavioural intentions towards them (recommendations, favourable attitudes towards the opening of a new store, low intentions to boycott, or repeat visits).

In the institutional field that interests us in this study, Eichholtzer (2010) also looked at the link between legitimacy and trust, revealing that the perceived legitimacy of the European Union is of fundamental importance in securing the trust and adherence of its citizens. In support of this theorising of the link between legitimacy and trust, the anticipatory nature of trust is to be noted. Trust manifests itself as a willingness or intention based on expectations or beliefs in the credibility and integrity of one's partner, as well as on presumptions of benevolence (Moorman et al., 1992). Considering that these contributions can be applied to consumer associations, we suggest that the perceived legitimacy of such an association, in the absence of prior experience, constitutes a determinant of intentions to trust.

In order for individuals to trust an organization, however, their vulnerability and the uncertainty of the situation must be taken into account (Deutsch, 1962; Mayer et al., 1995; Smith and Barclay, 1997). According to some researchers, vulnerability is even consubstantial to trust because one partner is generally in a situation of dependency on the 
other (Bartikowsky et al., 2007; Mayer et al., 1995). Although this approach has primarily been developed in the context of company/consumer relations, in which asymmetry favors the former, here we examine the perceived vulnerability of consumers in terms of their trust in associations that work to defend them.

\section{The role of the consumer's perceived vulnerability}

Vulnerability is a concept sometimes mistakenly likened to discrimination, stigmatisation or disadvantageous situations that stem from certain individual characteristics, whether biological (age, ethnicity, disability), psychosocial (economic status, level of education, literacy, problems of appearance) or related to one's state (grief or temporary fragility link to a particular situation) (Baker et al., 2005).

In reality, vulnerability is not a notion that is in principle associated with a category of individuals designated by others as being vulnerable ("perceived vulnerability") (Smith and Cooper-Martin, 1997). On the contrary, it is to be considered as a sentiment experienced by anyone who perceives himself as truly vulnerable ("actual vulnerability"). Furthermore, vulnerability is the result of an interaction between an individual and a situation. In the case of this research, it is the context of consumption that can bring about this "state of powerlessness that arises from an imbalance in marketplace interactions or from the consumption of marketing messages and products" (Baker et al., 2005: 134). For the consumer, it occurs when control is not in the individual's hands "within a context where consumption goals may be hindered and the experience affects personal and social perceptions of self" (Baker et al., 2005: 134). This lack of control creates "dependence on external factors [...] to create fairness in the marketplace" (Baker et al., 2005: 134).

Although it is true that an individual may present forms of fragility that are linked to a lack of physical capabilities (disability), particular sensitivities (allergies), mental difficulties or cognitive weaknesses (naïveté), vulnerability also stems from the way in which specific situational factors, in particular commercial environments in the broadest sense, can exacerbate the dangers that individuals must face (Morgan et al., 1995).

If finding a remedy for problems of asymmetry between professionals and members of the public is considered part of the role assigned to consumer associations (Chazal, 2000), then vulnerability is closely linked to the actions they take to protect consumers and ensure their well-being (Gorge et al., 2015). Baker et al. (2005) nonetheless point out that vulnerability and the need for protection are not interchangeable. While the members of a group under protection may feel vulnerable - the consumer being one of them -, belonging to that group 
does not necessarily imply that each individual in it feels fragile. Some authors (Martin, 1987; Sinay-Cytermann, 1994) have endeavoured to show that there are "abusive" consumers who are considerably overprotected in their dealings with professionals. Furthermore, some individuals may have a level of expertise and competency that is at least equal to that of their fellow contracting party (for example a banker looking for a loan, an IT engineer buying a computer, etc.). In fact, while the legislature has privileged a broad, equitable and abstract vision of consumer vulnerability, the way in which consumers perceive their own vulnerability can vary. As a result, the variability of this individual perception makes it important to examine its relationship with intentions to trust consumer associations. We conducted a qualitative study to clarify the nature of this link.

\section{Qualitative study and research hypotheses}

Qualitative study: methodology and results

The objective of the qualitative study was to examine the factors that can result in individuals placing their trust in consumer associations. Due to the variety of critical incidents recorded in our respondents' discourse, a total of 51 individual interviews were conducted. This high number of interviews allowed us to ensure "that there was no more additional information that could enrich the theory" (Thiétart, 2003: 216). Our respondents, recruited using the "snowball" method, had all encountered a problem in dealing with a professional (manufacturer, retailer, service provider, etc.). In their account of the steps they took, particular attention was paid to their decision whether or not to contact a consumer association. The interview guidelines were made up of three main sections: 1/ narration of the problem, actions taken and parties consulted; 2/ knowledge of consumer associations, their missions and representations of their actions; 3/ general expectations in terms of informing and defending consumers. The aim was to evaluate the level of respondents' knowledge of consumer associations and to understand how they perceive them, according to their needs and profiles. The sample was made up of individuals with varied sociodemographic characteristics, as well as differences in terms of their knowledge and use of consumer associations (Appendix 1). The interviews were recorded and transcribed in full. Thematic content analysis was conducted to identify the themes and sub-themes of the respondents' discourse. The authors separately coded the first 10 interviews before discussing their analytical frameworks, which they then combined. This framework was enriched as the data collection process advanced. It reveals the importance of the perceived legitimacy of consumer associations when it comes to intentions to trust them3: 
- Cognitive legitimacy develops through the history, actions and continuity of consumer associations. Aline (55) commented that "being around for a very long time" is an indicator of trustworthiness. This was confirmed by Béatrice (44): "I trust them because I know about their past". Nathalie (44) referred to the predictability of their activities: "I trust them because they have proved in the past that they can compel sectors to respond". The institutional nature of consumerism, with continuity over time, was also highlighted by Victor (60): "That's why I think we can trust them, because now they are well established". This "taken-for-grantedness" is summed up by Alice (34): “They're always there, where they're needed, when there are major problems, they're always there when something goes wrong". These comments illustrate the positive influence of cognitive legitimacy on intentions to trust consumer associations.

- The pragmatic legitimacy of associations is assessed in terms of their effectiveness and their ability to respond to the needs of their users. As Thierry (26) points out: "I really trust these consumer associations, who have really helped me in my choice of products". In more general terms, Mireille (50) told us: "I trust them because in everything that I have seen, heard and read, I realise that thanks to their intervention a lot of consumers have been successful or won their cases". Monique (59) feels that they are trustworthy and effective particularly because of their competency and expertise: "I think they're really credible. They have people who are highly specialised in each area". It is clear therefore that pragmatic legitimacy, which is based on the expertise and results obtained by consumer associations, has a positive influence on intentions to trust them.

- The moral legitimacy of associations, finally, corresponds to the social desirability of their actions. It is strongly linked to their perceived distance from the commercial world, the voluntary nature of their activities and their financial independence, as emphasised by Aurore (20): “Consumer associations have a positive image because they're not-for-profit organizations. So if there is no money at stake, you'd expect them to be a bit more impartial". Similarly, Cécile F. (52) commented: "I trust them because I feel as if they're not doing business, they're not helping companies to generate revenue". Another respondent, Cécile D. (48), also believes “they are reliable above all because they're not interested in anything except consumer interests". Intentions to trust associations are therefore positively influenced by their moral legitimacy.

Lastly, the results shed light on the role of perceived vulnerability in respondents' intentions to trust consumer associations. Antoine (52) points out that their mission is specifically to "defend people who don't have the capacity or the time to defend themselves", for example 
"when you're in a dispute and you feel a bit helpless". Similarly, for Christine (53), turning to an association for help is about "defending the consumer who is helpless in the face of a major retailer". These extracts suggest that the perceived vulnerability of consumers has a direct effect on the level of trust they are willing to place in associations. However, our respondents' discourse also points to the possibility that the level of consumers' vulnerability may act as a moderator in the relationship between the perceived legitimacy of associations and intentions to trust them. This is clear from remarks by Monique (59): "They have lawyers, and disputes can drag on and on, you know. They can settle disputes before the courts. These procedures can go on and on! They do a lot of work that we don't know about, you know! I have quite a few small problems to resolve and I might go to see them actually ... I'm afraid of being ripped off, I'm afraid of spending money for nothing, I don't like finding myself with poor-quality products, for example". This quotation shows that the pragmatic legitimacy of associations (the means at their disposal to defend her) influences the intention of this respondent to trust them (by considering contacting them) due to her high level of perceived vulnerability (fear of being “ripped off").

\section{Research hypotheses}

Based on all of the research studies cited above and the results of our qualitative study, we postulate that the perceived vulnerability of consumers positively influences their intention to trust consumer associations. This gives us the following hypothesis:

H1. The more consumers perceive themselves as vulnerable in dealing with commercial entities, the greater their intention to trust consumer associations.

Next, considering that intentions to support an organization are greater if that organization is perceived as legitimate (Eichholtzer 2010; Handelman and Arnold, 1999), we postulate that the perceived legitimacy of consumer associations has a positive effect on intentions to trust them. Furthermore, given the above explanations about the role of the consumer's perceived vulnerability in dealing with commercial entities, we assume that the correlation between the perceived legitimacy of associations and intentions to trust them is stronger when the individual feels vulnerable. For the more individuals feel unable to protect their own interests, the more likely they are to trust organizations which they feel are legitimately mandated to pursue this objective. Given that there are three facets to the perceived 
legitimacy of associations - cognitive, pragmatic and moral -, we make the following hypotheses (Figure 1):

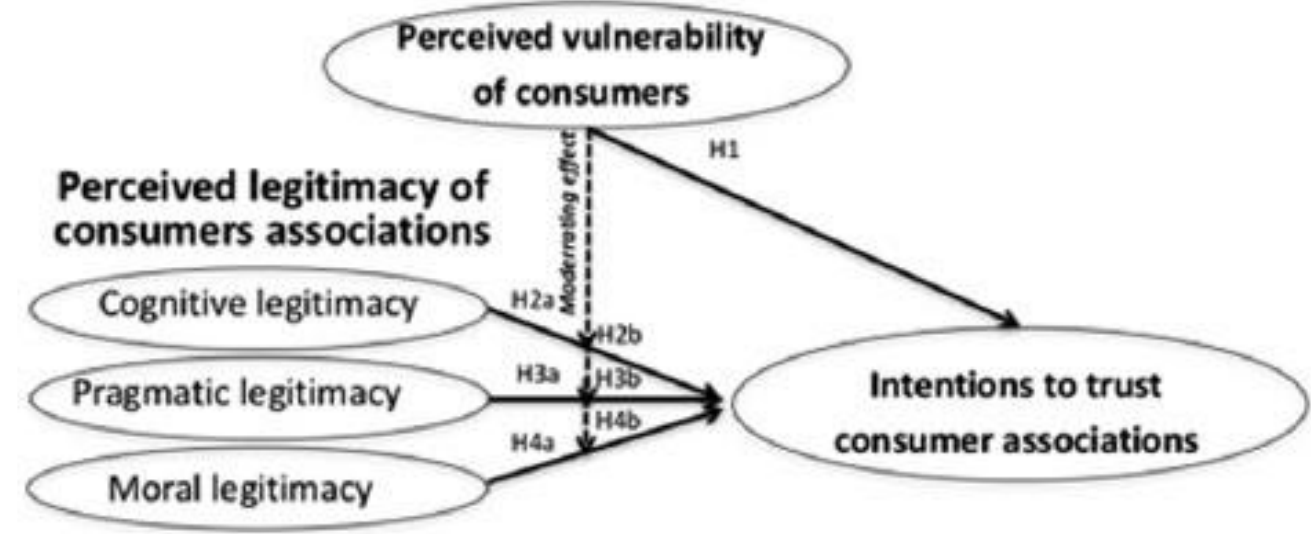

Figure 1. The effects of the legitimacy of consumer associations on intentions to trust them in accordance with the moderating role of their perceived vulnerability.

H2a. The more consumers perceive the cognitive legitimacy of consumer associations to be strong, the greater their intentions to trust them.

H2b. The correlation between the cognitive legitimacy of consumer associations and intentions to trust them is made stronger by the extent to which consumers feel vulnerable in their dealings with commercial entities.

$\mathrm{H} 3 \mathrm{a}$. The more consumers perceive the pragmatic legitimacy of consumer associations to be strong, the greater their intentions to trust them.

$\mathrm{H} 3 \mathrm{~b}$. The correlation between the pragmatic legitimacy of consumer associations and intentions to trust them is made stronger by the extent to which consumers feel vulnerable in their dealings with commercial entities.

H4a. The more consumers perceive the moral legitimacy of consumer associations to be strong, the greater their intentions to trust them.

H4b. The correlation between the moral legitimacy of consumer associations and intentions to trust them is made stronger by the extent to which consumers feel vulnerable in their dealings with commercial entities.

We conducted a quantitative study in order to test these research hypotheses. 


\section{Research methodology}

Study context: certified consumer associations

Only certified consumer associations4 were used for the purposes of this research. There are three reasons for this: the defence of consumer rights does not play a "preponderant" role in the activities of all non-certified associations (Laurent, 2009); these associations often have a low number of members, are not well known or representative; and do not necessarily satisfy the criterion of independence, which is a determining factor in perceptions of the legitimacy of consumerist bodies (Nabec et al., 2015).

\section{Collecting quantitative data}

A quantitative study was conducted using questionnaires administered online to an initial sample of 751 individuals. Only those respondents able to correctly cite a consumer association operating in France were retained. This selection process took place based on the following filter question: "Which consumer associations do you know?" The final sample included 315 individuals with varied profiles in terms of gender (48\% men, 52\% women), age (25\% aged $15-34,27 \%$ aged $35-49$, and $48 \%$ aged over 50$)$ and profession (33\% in a high socio-professional category, $28 \%$ in a low socio-professional category, and $39 \%$ not in work).

In order to verify that consumer associations can face problems of legitimacy and that there is variance in this variable, descriptive statistics (in particular means and standard deviations) were calculated for each dimension, revealing the presence of variance: cognitive legitimacy $($ mean $=4.32 ; \mathrm{SD}=1.22)$, pragmatic legitimacy $($ mean $=5.04 ; \mathrm{SD}=0.93)$ and moral legitimacy $($ mean $=5.14 ; \mathrm{SD}=1.25)$.

\section{Operationalisation of variables and measurement of constructs}

The scales used to measure legitimacy and intentions to trust were adapted from existing tools in the literature (Capelli and Sabadie, 2005). The perceived vulnerability scale was constructed using the comments recorded during the qualitative phase. These were 7-point Likert-type or differential semantic scales ( $1=$ totally disagree; $7=$ totally agree $)$. For each one, and having verified that the data could be factorised (KMO index and Bartlett's test), exploratory factorial analyses were conducted. To verify the structure obtained, confirmatory factorial analyses based on a Partial Least Squares5 (PLS) estimation model (Tenenhaus et al., 2005) were then carried out. To account for the fact that the variables did not quite follow 
a normal distribution, a Bootstrap procedure with 250 replications was implemented using PLS Path Modeling.

\section{Perceived legitimacy of a consumer association}

Perceived legitimacy was measured by adapting the scale used by Capelli and Sabadie (2005). This was developed in the context of the legitimacy of an advertising firm and presents the same facets as those identified in the qualitative phase and described in the literature (Bitektine, 2011; Suchman, 1995). The scale includes three dimensions (Table 1): cognitive legitimacy (stemming from the continuity of the activities of consumer associations over time, which makes their status beyond question); pragmatic legitimacy (linked to their capacity to effectively respond to the needs of their users, and to be easily identifiable and accessible with a view to helping them); and moral legitimacy (based on the societal value of their mission).

\section{Intentions to trust a consumer association}

The conative dimension of trust ("trusting intention") was measured using the same scale as McKnight et al. (2004), translated by Bartikowski et al. (2007). This scale traditionally includes four sub-dimensions: willingness to depend, follow advice, give information and make purchases. Here, it was adapted to the case of consumer associations and reduced following the statistical analyses carried out. It has a unidimensional five-item structure (Table 1) and reflects the belief that these associations can be depended on as well as willingness to follow their advice.

\section{Perceived vulnerability of consumers in dealing with commercial entities}

Two categories of scales can be used to measure consumer vulnerability. Those in the first category measure the level of perceived weakness in certain categories of the population such as children or the elderly. Those in the second, which better correspond to the present research, measure vulnerability as perceived by respondents themselves rather than external observers. Such scales have been used in social marketing studies, for example to measure the fragility generated by messages that target fear in certain preventive publicity campaigns against the risks of smoking or anorexia (Janz and Becker, 1984; Maillard-Wilhelm, 2014; Werle et al., 2010). However, these measurements are mono-item and difficult to transpose to the context of this paper. Given the lack of any truly satisfactory measurement tool, we constructed an ad hoc five-item scale using the comments recorded during the qualitative 
study (Table 1). Following the COARSE procedure (Rossiter, 2002), we defined the focus of the measurement as vulnerability as perceived by the individual consumers themselves.

We treated consumers as the evaluators of their own state. The fact of "being a consumer" then specifies the dimensions of the judgement and the component parts of its measurement.

Table I. Validity, rellability and confirmatory analyses of measurement scales.

\begin{tabular}{|c|c|c|c|c|c|c|}
\hline Construct & Structure & Items & Loadings & $\begin{array}{l}\text { Cronbach's } \\
\text { Alpha }\end{array}$ & $\begin{array}{l}\text { DG's } \\
\text { Rho }\end{array}$ & $\begin{array}{l}\text { Convergent } \\
\text { validity (AVE) }\end{array}$ \\
\hline \multirow[t]{11}{*}{ Legitimacy } & \multirow{4}{*}{$\begin{array}{l}\text { Cognitlve } \\
\text { legitimacy } \\
\text { (4 Items) }\end{array}$} & $\begin{array}{l}\text { Today's consumer assoclations represent continulty in terms of what they } \\
\text { were previously }\end{array}$ & 0.947 & & & \\
\hline & & $\begin{array}{l}\text { The actions of consumer assoclations have not varied since they were first } \\
\text { established }\end{array}$ & 0.792 & 0.93 & 0.95 & 0.82 \\
\hline & & Consumer assoclations continue to pursue their m/ssions as in the past & 0.940 & & & \\
\hline & & $\begin{array}{l}\text { Consumer assoclations carry out missions identical to those at the time } \\
\text { they were first established }\end{array}$ & 0.933 & & & \\
\hline & \multirow{3}{*}{$\begin{array}{l}\text { Pragmatic } \\
\text { legitimacy } \\
\text { ( } 3 \text { Items) }\end{array}$} & Consumer assoclations are ineffective (I)-effectlve (7) & 0.877 & & & \\
\hline & & Consumer assoclations are unknown (1)-well known (7) & 0.761 & 0.76 & 0.86 & 0.67 \\
\hline & & Consumer assoclations are difficult to contact (1)-easy to contact (7) & 0.808 & & & \\
\hline & \multirow{4}{*}{$\begin{array}{l}\text { Moral } \\
\text { legitimacy } \\
\text { (4 Items) }\end{array}$} & $\begin{array}{l}\text { Consumer assoclations seek to defend their own Interests-seek to defend } \\
\text { consumer Interests }\end{array}$ & 0.853 & & & \\
\hline & & $\begin{array}{l}\text { Consumer assoclations are sometimes financed by companles-are financed } \\
\text { Independently of companles }\end{array}$ & 0.872 & & & \\
\hline & & $\begin{array}{l}\text { Consumer assoclations carry out product comparison tests on behalf of } \\
\text { certaln brands-carry out comparison tests with complete independence } \\
\text { from the interests of brands }\end{array}$ & 0.859 & 0.89 & 0.92 & 0.75 \\
\hline & & $\begin{array}{l}\text { Consumer assoclations seek to promote Ideological and political objectives } \\
- \text { strive to Inform and defend consumers with complete objectlvity. }\end{array}$ & 0.878 & & & \\
\hline \multirow[t]{5}{*}{$\begin{array}{l}\text { Intention to } \\
\text { trust }\end{array}$} & \multirow[t]{5}{*}{5 Items } & $\begin{array}{l}\text { I feel I can depend on consumer assoclations to help me resolve a major } \\
\text { consumption problem }\end{array}$ & 0.965 & & & \\
\hline & & $\begin{array}{l}\text { I can always rely on consumer assoclations in the event of a serlous } \\
\text { problem with a company }\end{array}$ & 0.958 & 0.98 & 0.98 & 0.91 \\
\hline & & $\begin{array}{l}\text { If I have to resolve a serious problem linked to consumption, I would feel } \\
\text { reassured If I could rely on consumer assoclations }\end{array}$ & 0.962 & & & \\
\hline & & $\begin{array}{l}\text { In the event of a consumption problem that requires legal assistance, I } \\
\text { would willingly call on the services of consumer assoclations }\end{array}$ & 0.956 & & & \\
\hline & & When a consumption problem arises, I trust consumer assoclations & 0.949 & & & \\
\hline \multirow{5}{*}{$\begin{array}{l}\text { Percelved } \\
5 \text { Items } \\
\text { vulnerability }\end{array}$} & & As a consumer, I feel vulnerable in dealing with professionals & 0.974 & & & \\
\hline & & $\begin{array}{l}\text { My status as a consumer often gives me the Impression that I am in a } \\
\text { position of weakness compared to professionals }\end{array}$ & 0.972 & 0.96 & 0.99 & 0.95 \\
\hline & & As a consumer, I often feel III-equipped to deal with professionals & 0.970 & & & \\
\hline & & When dealing with professionals, I feel fraglle as a consumer & 0.975 & & & \\
\hline & & $\begin{array}{l}\text { As a consumer, I find it difficult to defend myself when dealing with } \\
\text { professionals }\end{array}$ & 0.969 & & & \\
\hline
\end{tabular}

DG's Rho: Dillon-Goldstein's Rho; AVE: average varlance extracted.

Table 2. Discriminant analysis of legitimacy measurement scale.

\begin{tabular}{llll}
\hline & \multicolumn{2}{c}{ Discriminant validity of constructs } \\
\hline & Moral legitimacy & Pragmatic legitimacy & Cognitive legitimacy \\
\hline Moral legitimacy & 1 & & \\
Pragmatic legitimacy & 0.25 & 0.16 & 1 \\
Cognitive legitimacy & 0.12 & 1 & \\
\hline
\end{tabular}




\section{Evaluating the psychometric quality of the scales}

Confirmatory factorial analyses enabled us to validate the factorial structures proposed, in line with the exploratory factorial analysis. The factor loadings are all greater than 0.8 (or close to this threshold) and can therefore be considered satisfactory (Fornell and Larker, 1981) (Table 1). Cronbach's Alpha and Dillon-Goldstein's Rho were then used to evaluate the reliability of the measurement tools. The coefficients obtained are all greater than 0.7 , satisfying Nunnally's acceptability threshold (1978). Convergent validity was confirmed by the fact that the factor loading of each indicator is significant $(t>1.96)$ and greater than or equal to 0.7 (Anderson and Gerbing, 1988). An average variance extracted (AVE) test provided an additional indication of convergent validity. It must be greater than or equal to 0.5 according to the approach of Fornell and Larcker (1981) and in this case proved satisfactory across all scales (Table 1). Finally, discriminant validity was confirmed: the convergent validity of the constructs is greater than the square of the correlation between them (Fornell and Larker, 1981). The results therefore show that all scales are reliable and valid (Tables 1 and 2).

\section{Results}

Our hypotheses were tested using regression analysis conducted with SPSS 22.0 in accordance with the recommendations of Preacher and Hayes (2004, 2008), using model 1 of Hayes's procedure (2012) and a Bootstrap procedure with 5,000 replications. This approach, recommended by Cadario and Parguel (2014), makes it possible to analyse moderator effects without a priori discretization of the moderator variables being studied. The effect of each dimension in the legitimacy of associations (cognitive, pragmatic and moral), of the perceived vulnerability of individuals and of their interaction with intentions to trust was analysed using a distinct regression model. A total of three models were developed (Model 1: effect of cognitive legitimacy; Model 2: effect of pragmatic legitimacy; Model 3: effect of moral legitimacy - see Tables 3, 4 and 5). In each one, we controlled for the effects of the two remaining dimensions of legitimacy by introducing them as covariables. Lastly, interaction effects were represented graphically using the procedure developed by Aiken and West (1991) (Figures 2, 3 and 4). The variables used were calculated based on the means of the scores obtained by the items that made up each dimension. 


\section{Direct effect of perceived vulnerability on intentions to trust}

The direct effect of the perceived vulnerability of individuals and their intentions to trust consumer associations (H1) was tested in each of the three regression models (Model 1: $\beta=$ $0.11 ; p<0.01 ;$ Modele 2: $\beta=0.13 ; p<0.01$; Model $3: \beta=0.11 ; p<0.001)$. It is significantly positive (H1 is validated). This means that the more vulnerable individuals feel in dealing with commercial entities, the greater their intentions to trust consumer associations. Inversely, the less they feel vulnerable, the lower their intentions to trust these associations (Tables 3 to 5).

Table 3. Effect of cognitive legitimacy of consumer associations on intentions to trust them (Model 1).

Intentions to trust consumer associations $(\mathrm{N}=315)$

\begin{tabular}{|c|c|c|c|c|}
\hline & Coef & $\mathrm{Se}$ & $t^{*}$ & $p$ \\
\hline Constant & 0.83 & 0.35 & -2.42 & 0.02 \\
\hline Vulnerability & 0.11 & 0.04 & 3.00 & 0.00 \\
\hline $\begin{array}{l}\text { Cognitive legitimacy } \\
\text { Interaction }\end{array}$ & 0.13 & 0.05 & 2.38 & 0.02 \\
\hline $\begin{array}{ll}\text { Cognitive } & \text { legitimacy } \\
\text { Vulnerability } & \\
\text { Covariables } & \end{array}$ & $* 0.02$ & 0.02 & 0.79 & 0.43 \\
\hline Pragmatic legitimacy & 0.57 & 0.07 & 4.68 & 0.00 \\
\hline $\begin{array}{l}\text { Moral legitimacy } \\
\text { R2 =0 42. } F=4550(\mathrm{n}<1\end{array}$ & 0.25 & 0.05 & 8.22 & 0.00 \\
\hline
\end{tabular}

* The values of Student's t-test above [1.96] indicate parameters significant at the 5\% threshold.

Table 4. Effect of pragmatic legitimacy of consumer associations on intentions to trust them (Model 2).

Intentions to trust consumer associations $(\mathrm{N}=315)$

Coef $\mathrm{Se} \quad t^{*} \quad p$

\begin{tabular}{lcccc}
\hline Constant & 3.15 & 0.32 & 9.66 & 0.00 \\
Vulnerability & 0.13 & 0.04 & 3.60 & 0.00 \\
$\begin{array}{l}\text { Pragmatic legitimacy } \\
\begin{array}{l}\text { Interaction } \\
\text { Pragmatic legitimacy * Vulnerability-0.08 }\end{array}\end{array}$ & 0.59 & 0.07 & 8.59 & 0.00 \\
$\begin{array}{l}\text { Covariables } \\
\text { Cognitive legitimacy }\end{array}$ & 0.03 & -2.43 & 0.02 \\
$\begin{array}{l}\text { Moral legitimacy } \\
\text { R2 }=0.43 ; F=47.32(\mathrm{p}<1 \%)\end{array}$ & 0.13 & 0.05 & 4.57 & 0.00 \\
\end{tabular}

$*$ The values of Student's t-test above [1.96] indicate parameters significant at the $5 \%$ threshold. 
Table 5. Effect of moral legitimacy of consumer associations on intentions to trust them (Model 3). Intentions to trust consumer associations $(\mathrm{N}=315)$

\begin{tabular}{|c|c|c|c|c|c|}
\hline$\overline{\text { Coef }}$ & $\mathrm{Se}$ & $p$ & & & \\
\hline \multicolumn{3}{|c|}{ Constant } & 0.36 & 4.37 & 0.00 \\
\hline \multicolumn{3}{|c|}{ Vulnerability } & 0.04 & 3.14 & 0.00 \\
\hline \multicolumn{2}{|c|}{ Moral legitimacy } & 0.25 & 0.05 & 4.67 & 0.00 \\
\hline \multicolumn{3}{|c|}{ Moral legitimacy * Vulnerability -0.02} & 0.03 & -0.70 & 0.48 \\
\hline \multicolumn{3}{|c|}{ Cognitive legitimacy } & 0.05 & 2.30 & 0.02 \\
\hline \multicolumn{3}{|c|}{$\begin{array}{ll}\text { Pragmatic legitimacy } & 0.58 \\
\mathrm{R} 2=0.42 ; F=45.45(\mathrm{p}<1 \%) & \end{array}$} & 0.07 & 8.37 & 0.00 \\
\hline
\end{tabular}

Figure 2. Interaction effects between the cognitive legitimacy of consumer associations and perceived vulnerability on intentions to trust them

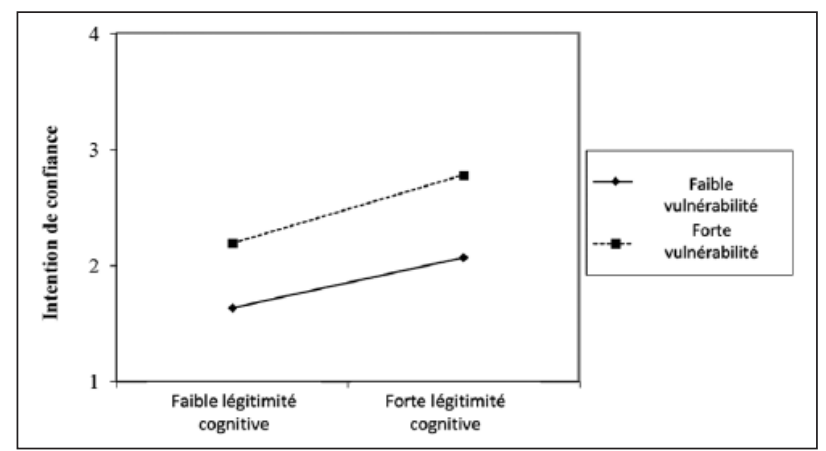

Figure 3. Interaction effects between the pragmatic legitimacy of consumer associations and perceived vulnerability on intentions to trust them

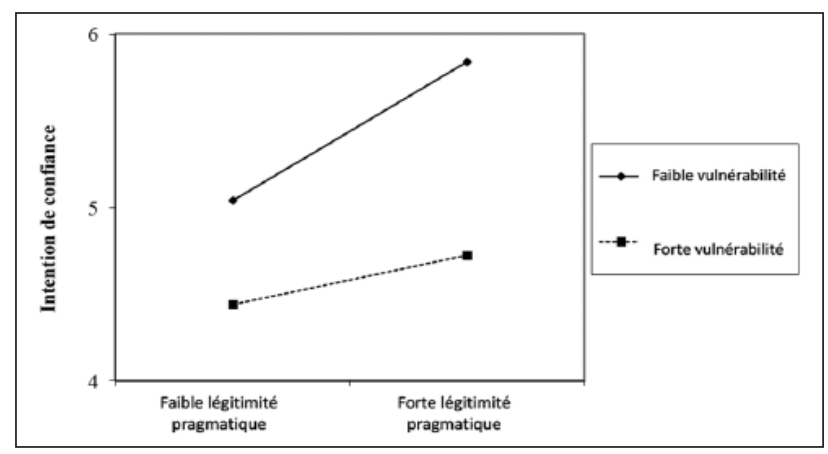


Figure 4. Interaction effects between the moral legitimacy of consumer associations and perceived vulnerability on intentions to trust them

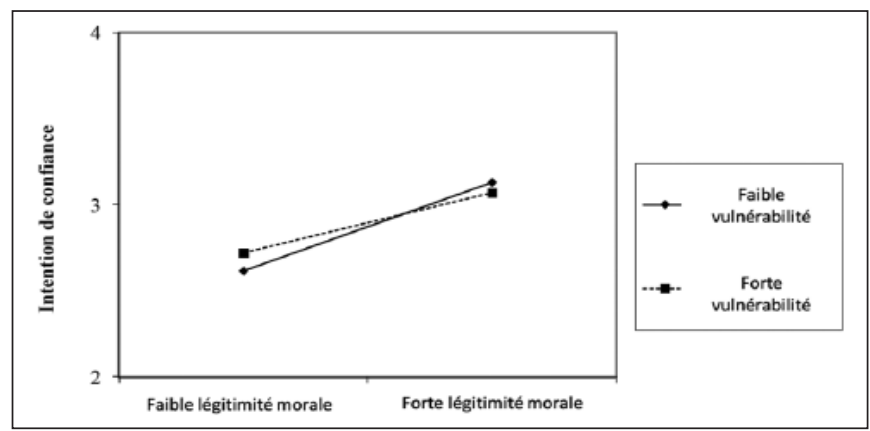

Effects of cognitive legitimacy and perceived vulnerability on intentions to trust consumer associations

The effects of the cognitive legitimacy of consumer associations, the perceived vulnerability of individuals and their interaction on intentions to trust these associations (H2) were analysed in the first regression model (Model 1: R2 $=42 \% ; F=45.50^{* * *}$ ) (Table 3; Figure 2). The results show a direct significant effect of the perceived cognitive legitimacy of consumer associations on intentions to trust them $(\beta=0.13 ; p<0.05)(\mathrm{H} 2 \mathrm{a}$ is validated). People therefore have greater intentions to trust consumer associations if they deem their presence in the institutional landscape to be "taken for granted" and to represent the continuity of their existence. However, the interaction between the perceived cognitive legitimacy of consumer associations and the perceived vulnerability of individuals is not significant ( $\beta=0.02 ; p=0.43$ ) (Figure 2 ), contrary to what was predicted by $\mathrm{H} 2 \mathrm{~b}$. In other words, perceived cognitive legitimacy explains people's intentions to trust these associations regardless of their level of perceived vulnerability in dealing with commercial entities $(\mathrm{H} 2 \mathrm{~b}$ is not validated).

Effects of pragmatic legitimacy and perceived vulnerability on intentions to trust consumer associations

The effects of the pragmatic legitimacy of consumer associations, the perceived vulnerability of individuals and their interaction on intentions to trust these associations (H3) were analysed in the second regression model (Model 2: R2 $=43 \% ; F=47.32 * * *$ ) (Table 4; Figure 3). The perceived pragmatic legitimacy of consumer associations positively and significantly influences the intentions of individuals to trust them $(\beta=0.59 ; p<0.01)(\mathrm{H} 3 \mathrm{a}$ is 
validated). In other words, the more people deem consumer associations capable of helping them and of effectively responding to their problems, the greater their intentions to trust them. Inversely, when they perceive these associations to be relatively inaccessible, difficult to identify and incapable of fulfilling their mission, they display lower intentions to trust them. Nonetheless, our analyses reveal a significant and negative interaction effect between the pragmatic legitimacy of consumer associations and the perceived vulnerability of individuals $(\beta=-0.08 ; p<0.05)$ (Figure 3$)$. In other words, while the effect of pragmatic legitimacy on intentions to trust is always positive, it is even stronger when individuals do not feel vulnerable in dealing with commercial entities. Inversely, this effect is weaker when consumers do feel vulnerable. This means that the more consumers perceive themselves as vulnerable in dealing with commercial businesses, the less the perceived capacity of consumer associations to act in a way that protects their interests has a significant influence on their intentions to trust these associations (compared to individuals who do not feel very vulnerable). This finding runs counter to $\mathrm{H} 3 \mathrm{~b}$, which predicted that the perceived vulnerability of individuals would lead them to be more trusting of consumer associations if they perceived them as capable of mobilising resources to protect them $(\mathrm{H} 3 \mathrm{~b}$ is not validated).

Effects of moral legitimacy and perceived vulnerability on intentions to trust consumer associations

The effects of the perceived moral legitimacy of consumer associations, the perceived vulnerability of individuals and their interaction on intentions to trust these associations (H4) were analysed in the third regression model (Model 3: R2 $=42 \% ; F=45.45^{* * *}$ ) (Table 5). The results show that the moral legitimacy of consumer associations significantly influences intentions to trust them $(\beta=0.25 ; p<0.01)(\mathrm{H} 4 \mathrm{a}$ is validated). This means that the more consumers deem consumer associations to be in pursuit of legitimate objectives for society, the greater their intentions to trust them. This finding is not moderated by the effect of the perceived vulnerability of individuals $(\beta=-0.02 ; p=0.48)$; in other words, this effect is neither stronger nor weaker as the level of individuals' perceived vulnerability changes (Figure 4) (H4b is not validated).

\section{Discussion: implications, limitations and future research avenues}

The objective of this research was to test the explanatory effect of the legitimacy of consumer associations on intentions among members of the public to trust them and also to identify, 
within this relationship, the direct and moderating role of individuals' perceived vulnerability in dealing with commercial entities. It reveals that consumers are more likely to trust consumer associations if they perceive them as having always pursued the same missions (cognitively legitimate), as effective, accessible and well known (pragmatically legitimate), and as useful to society (morally legitimate). Furthermore, our results show that intentions to trust are greater when consumers feel vulnerable in dealing with commercial businesses. Although in line with our hypotheses, these two findings take on a different shape when the moderator effect of vulnerability on the relationship between legitimacy and intentions to trust is taken into account: this moderator only plays a role in the case of pragmatic legitimacy. And, contrary to what H3b predicted, the effect of pragmatic legitimacy is stronger when people do not feel vulnerable in dealing with commercial entities. In other words, the less individuals perceive themselves as fragile or in a position of weakness in relation to professionals, the more the perceived effectiveness, accessibility and reputation of consumer associations have an influence on their intentions to trust these associations. This finding contradicts the hypothesis that stemmed from previous research studies (Roux, 2012; Roux et al., 2015), which suggested that the effectiveness, accessibility and reputation of consumer associations would generate greater trust among vulnerable consumers. However, the results of our research reveal no interaction effect between the cognitive and moral legitimacy of consumer associations and the perceived vulnerability of individuals in dealing with commercial entities. In other words, it matters little whether perceived vulnerability is high or low when the effect of perceived legitimacy on intentions to trust relates to the institutional or socially desirable nature of associations. It is therefore essential for these associations to promote their experience, their history and impartiality if they are to convince consumers as a whole, i.e. not only prioritising members of the public who see themselves as vulnerable but also those who feel a less pressing need for their interests to be protected.

\section{Theoretical implications}

These results build on previous research on feelings of vulnerability among consumers (Baker et al., 2005) and the perceived legitimacy of organizations (Capelli and Sabadie, 2005; Suchman, 1995). They shed light on the way in which associations must account for the profiles of their users, in particular their perceived vulnerability. Consumer associations primarily target members of the public who perceive themselves as vulnerable in dealing with 
commercial businesses. Indeed, this is what justifies their existence and actions for these users.

First of all, the results of this study confirm that, on the whole, people's perceived vulnerability does influence their intentions to trust consumer associations. Using a different context, they complement previous studies which showed that the more individuals are vulnerable, the more likely they are to be trusting, and the more positive are their expectations with regard to the behaviour of others (Luhmann, 1988). In this respect, our research also builds on earlier research on intentions to trust in organizations, highlighting the appeal in theoretical terms of accounting for the perceived vulnerability of individuals in this process (Baker et al., 2005).

Second, our results show that vulnerability moderates the influence of pragmatic legitimacy on intentions to trust: these intentions are greater when individuals do not feel particularly vulnerable in dealing with commercial entities. This finding makes a further contribution to the theory: the least vulnerable people are more likely to trust consumer associations when they consider them to be effective, well known and easy to contact. This suggests that the least vulnerable people are better placed to see consumer associations as resources when these conditions are met. In contrast, the most vulnerable people, who feel they "lack control", intend to trust associations regardless of their pragmatic legitimacy. Perhaps they do not feel in a position to judge this legitimacy. These important findings are new to the literature.

Finally, while the relationship between legitimacy and intentions to support a company had already been highlighted (Handelman and Arnold, 1999), the link between the three dimensions of legitimacy judgements (Sabadie and Capelli, 2009; Suchman, 1995) and intentions to trust a consumer association had not previously been measured. This study reveals that legitimacy can be used as a potential lever for generating greater trust, including in non-commercial organizations, whose legitimacy is also being questioned (Roux et al., 2015; Vestergaard, 2014).

\section{Implications for consumer associations}

First, this research emphasises the importance of consumer associations to consider various means of reinforcing perceptions of their legitimacy. The steps that can be taken are complex as they depend on time and the power play in the institutional landscape, which leaves the consumer movement with varying levels of power. In this regard, the role of the State is primordial. A reduction in public financing is likely to undermine the power of consumer 
associations and further erode what little means they have of securing recognition in an informational landscape that is already overcrowded (Nabec et al., 2015).

Furthermore, it is essential for consumer associations to be able to communicate the effectiveness of their activities and any successful outcomes they achieve in particular cases or in defending certain rights. As things stand, their daily efforts on the ground, as well as their active contribution to many consultative bodies, receive little recognition. The first recommendation would therefore be to better highlight these roles so as to reinforce perceptions of their pragmatic legitimacy and thereby the levels of trust they can generate. At little cost, they could for example include in their various channels of communication (brochures, websites, etc.) testimonials from consumers who sought their help so as to share the outcomes of their intervention. As recommended in a report by Laurent (2009) on the world of consumerism, it would also be interesting to further reflect on the notion of performance measurement in associations. However, the indicators to be used remaind to be determined, bearing in mind that associations must retain a certain flexibility so as to respond as effectively as possible to heterogenous and complex on-the-ground realities. Lastly, in relation to moral legitimacy, while associations are considered to be independent of commercial entities, it is important for their users to be certain of this. It is therefore essential that there be no doubt about the objectives these associations pursue, dispelling any suspicion of collusion between manufacturers and associations in the context of comparative tests (Roux et al., 2015). While UFC-Que Choisir is currently developing an initiative called "La Note" to enable consumers to identify the best-ranked products in its comparative tests, the fact that professionals can obtain the right to use this "grade" when they pay for a licence6 could, despite the precautions taken by the association, be a source of confusion in a climate of acute scepticism (Darke et al., 2008).

Second, this study has highlighted the importance of people's perceived vulnerability in dealing with professionals in efforts to explain their intentions to trust consumer associations. As well as looking at the sociodemographic profiles of their target users, associations should also strive to better understand this variable. It is important to take perceived vulnerability into account when planning initiatives that are adapted to such profiles. The idea here is that associations manage to be perceived as effective and thereby generate high levels of trust among the most fragile members of the public, who must therefore be identified. 


\section{Limitations and future research}

This study carries a certain number of limitations that point to future research avenues. First of all, it only looked at certified consumer associations. It would be interesting to generalise these findings to other types of organizations set up to defend consumers, such as noncertified associations whose actions in some cases are just as effective. Similarly, the external validity of this study could be extended to, among others, online consumer groups, the websites of lawyers available to assist them, as well as TV and radio programmes which directly participate in the resolution of certain disputes.

Second, this study could be extended by examining the perceived legitimacy of each consumer association. We focused on overall perceptions, considering associations as an institution with a shared mission. An extension of this would involve comparing the differences in perceptions between these organizations so as to help them individually to improve their performance (Laurent, 2009).

Third, an individual moderator variable was introduced in this research: the perceived vulnerability of consumers in dealing with commercial entities. This is a very general approach and overlooks any variations in vulnerability from one consumption situation to the next. These should be explored separately since a consumer may feel vulnerable when taking out a telephone contract but less so when choosing a product in his or her area of expertise, such as sports equipment. It would also be interesting to explore the moderator effect of other individual variables such as one's propensity to trust others (Rotter, 1967; 1971; 1980) or to resist consumption (Roux, 2007; Banikéma and Roux, 2014). Perceived risk, which is an antecedent of trust (Benamour, 2000; Filser, 1998; Lewis and Weigert, 1985; Mitchell, 1999), could also be a variable worth considering given this link between trust and the perception of risks (Benamour, 2000).

These include the financial risk of losing money by subscribing to a consumer association (if a successful outcome is not achieved); the risk of wasting time on procedures, particularly if the financial damages are insubstantial; the psychological risk stemming from selfdisappointment in the event of failure; or the risk associated with the anxiety individuals may feel during lengthy procedures with sometimes uncertain outcomes. Fourth, beyond these individual variables, situational factors can explain an individual's intention to trust an association. It would be useful to take into account the mood of respondents at the time of the study, the time of year or the role played by friends and loved ones. Our findings therefore open up many different research avenues at the intersection between questions about 
legitimacy, trust and accounting for the vulnerability of individuals in the field of consumption.

\section{Notes}

1. As an extension of the French Code de la consommation, passed into law on 26 July 1993, more recent legislation dated 17 March 2014, known as the "loi Hamon", recognises the existence of group actions and offers associations new ways to defend consumers collectively.

2. It is very much an intention that we are trying to measure, rather than directly measuring existing levels of trust, as just 5\% of French people were members of a consumer association 10 years ago (CREDOC, 2005: 19). Despite a high level of trust overall, this study also points to the erosion of civic engagement with consumer associations. The largest of these associations in France - UFC Que-Choisir - currently has just 140,000 members, even though its monthly publication Que Choisir is said to reach 400,000 subscribers and 4.5 million readers (http://www.conso.net/content/ufc-que-choisirassociation-de-consommateurs).

3. Only aspects relating to the role of legitimacy and vulnerability in intentions to trust are presented; the study also pursued complementary objectives but which are not detailed in this article.

4. State certification indicates that an association meets three criteria (www.conso.net): one relating to its activities (must have been in existence for one year and demonstrate effective public action with a view to defending the interests of consumers); representation (at least 10,000 subscribers in the case of national associations); and independence from commercial entities.

5. There are several justifications for the use of PLS (Chin and Newsted, 1999; Fernandez, 2012), in particular the novel nature of the phenomenon being studied and the fact that the variables do not respect the condition of normality.

6. This licence covers the management and monitoring costs borne by Véritas, which acts as a third-party intermediary between UFC and professionals wishing to use "La Note", with the balance of monies received placed by the association into an endowment fund for informational and educational campaigns targeting consumers. 


\section{Bibliography}

Aiken LS et West SG (1991) Multiple Regression: Testing and Interpreting Interactions. Newbury Park CA: SAGE.

Anderson JC et Gerbing DW (1988) Structural equation modeling in practice: a review and recommended two-step approach. Psychological Bulletin 103: 411-423.

Arnold SJ, Handelman J et Tigert DJ (1996) Organizational legitimacy and retail store patronage. Journal of Business Research 35(3): 229-239.

Aurier P, Bénavent C et N'Goala G (2001) Validité discri- minante et prédictive des composantes de la relation à la marque. Congrès de l'Association Française du Marketing, Deauville, 22-23 Mai.

Azar-Baud MJ (2016) La mise en œuvre des droits des consommateurs : ce que l'action de groupe va chan- ger. In: Roux D et Nabec L (éds) Protection des consommateurs. Les nouveaux enjeux du consumé- risme. Cormelles-le-Royal: EMS, 193-204.

Baker SM, Gentry JW et Rittenburg TL (2005) Building understanding of the domain of consumer vulnerability. Journal of Macromarketing 25(2): 128-139.

Banikéma A et Roux D (2014) La propension à résister du consommateur : contribution a l'étude d'une disposition à s'opposer aux tentatives d'influence marchande. Recherche et Applications en Marketing 29(2): 34-59.

Bartikowski B, Chandon JL et Müller B (2007) Mesurer la confiance des internautes dans les sites web marchands : adaptation de l'échelle de McKnight, Kacmar et Choudhury (2002). Working Paper, CERGAM: Université d'Aix-Marseille.

Benamour Y (2000) Confiance interpersonnelle et confiance institutionnelle dans la relation client- entreprise de service : une application au secteur bancaire français. Thèse de doctorat en sciences de gestion: Université Paris Dauphine.

Benedicktus RL, Brady MK, Darke PR et Voorhees CM (2010) Conveying trustworthiness to online consu- mers: reactions to consensus, physical store presence, brand familiarity, and generalized suspicion. Journal of Retailing 86(4): 310-323.

Bidault F et Jarillo JC (1995) La confiance dans les tran- sactions économiques. In: Bidault F, Gomez PY et Marion G (éds) Confiance, Entreprise et Société. Paris: Eska, 109-123.

Bihl-Willette L (1984) Une histoire du mouvement consommateur : mille ans de lutte. Paris: Aubier.

Bitektine A (2011) Towards a theory of social judgments of organizations: the case of legitimacy, reputation, and status. Academy of Management Review 36(1): 151-179. 
Bourdieu J et Pinto L (éds) (2013) Pauvre consommateur. Actes de la recherche en sciences sociales 199. Paris: Seuil.

Bryce HJ (2007) The public's trust in nonprofit organi- sations. California Management Review 49(4): 112-

131.

Buskirk RH et Rothe JT (1970) Consumerism. An interpretation. Journal of Marketing 34(4): $61-65$.

Cadario R et Parguel B (2014) Reconsidérer la discréti- sation des variables quantitatives : vers une nouvelle analyse de modération dans la recherche expérimen- tale. Recherche et Applications en Marketing 29(4): 1-18.

Calais-Auloy J et Steinmetz F (1996) Droit de la consom- mation. Paris: Dalloz.

Capelli S et Sabadie W (2005) La légitimité d'une commu- nication sociétale : le rôle de l'annonceur. Recherche et Applications en Marketing 20(4): 53-70.

Chaney D et Ben Slimane K (2014) La grille néo-insti- tutionnelle au bénéfice de l'élargissement du marke- ting à des dimensions institutionnelles. Recherche et Applications en Marketing 17(2): 99-117.

Chatriot A (2004) Qui défend le consommateur? Associations, institutions et politiques publiques en France (1972-2003). In: Chatriot A, Chessel M-E et Hilton M (éds) Au nom du consomma- teur. Consommation et politique en Europe et aux Etats-Unis au XXe siècle. Paris: La Découverte, 165-181.

Chazal JP (2000) Vulnérabilité et droit : le développement de la vulnérabilité. Grenoble: Presses Universitaires de Grenoble.

Chessel M-E (2012) Consommateurs engagés à la Belle Epoque. La ligue sociale d'acheteurs. Paris: Presses de Sciences Po.

Chessel M-E (2016). Postface. Consommation : les «nouveautés » au regard de l'histoire. In: Roux D et Nabec L (éds) Protection des consommateurs : les nouveaux enjeux du consumérisme. Cormelles-le- Royal: EMS, Collection Versus, 205-211.

Chin WW et Newsted PR (1999) Structural equation ana- lysis with small samples using partial least squares. In: Hoyle R (éd.) Statistical Strategies for Small Sample Research. Londres: SAGE, 307-341.

Chouk I et Perrien J (2003) Les déterminants de la confiance du consommateur lors d'un achat sur un site marchand : proposition d'un cadre conceptuel préliminaire. Centre de recherche DMSP, cahier 318: 1-19. 
Cissé-Depardon K et N'Goala G (2009) Les effets de la satisfaction, de la confiance et de l'engagement vis- à-vis d'une marque sur la participation des consom- mateurs à un boycott. Recherche et Applications en Marketing 24(1): 43-67.

Darke PR, Ashworth LTA et Ritchie RB (2008) Damage from corrective advertising: causes and cures. Journal of Marketing 72(6): 81-97.

Deutsch M (1962) Cooperation and trust: some theore- tical notes. Nebraska Symposium on Motivation 10: 275-318.

Eichholtzer M (2010) Transparence, légitimité et confiance dans la gouvernance européenne. Mémoire de séminaire. Lyon: Institut d'Etudes Politiques de Lyon.

Fernandez V (2012) En quoi l'approche PLS est-elle une méthode à (re)découvrir pour les chercheurs en mana- gement ? Management 15(1): 101-123.

Filser M (1998) Confiance et comportement du consom- mateur. Economies et Sociétés, Sciences de Gestion Série S.G. 8-9: 279-294.

Fontaine L (2014) Le Marché. Histoire et usages d'une conquête sociale. Paris: Éditions Gallimard, NRF Essais.

Fornell C et Larker DF (1981) Evaluating structural equa- tions models with unobservable variables and measu- rement error. Journal of Marketing Research 18(1): 39-50.

Gabaix X, Landier A et Thesmar D (2012) Protection du consommateur : rationalité limitée et régulation. Paris: Rapport du Conseil d'Analyse Économique.

Gide C (1898/1931) Principes d'économie politique. Paris: Larose \& Forcel. http://classiques.uqac.ca/ classiques/gide_charles/principes_economie_pol/ principes_eco_pol.html

Gorge H, Özçağlar-Toulouse N et Toussaint S (2015) Bien-être et well-being dans la consommation : une analyse comparative. Recherches et Applications en Marketing 30(2): 104-123.

Guibert N (1999) La confiance en marketing : fondements et applications. Recherche et Applications en Marketing 14(1): 1-19.

Gurviez P et Korchia M (2002) Proposition d'une échelle de mesure unidimensionnelle de la confiance dans la marque. Recherche et Applications en Marketing 17(3): 41-61.

Gustafsson A, Johnson MD et Roos I (2005) The effects of customer satisfaction, relationship commitment dimensions, and triggers on customer retention. Journal of Marketing 69(4): 210-218.

Handelman JM et Arnold SJ (1999) The role of marketing actions with a social dimension: appeals to the ins- titutional environment. Journal of Marketing 63(3): 33-48. 
Hayes SC (2012) Humanistic psychology and contextual behavioural perspectives. Psychotherapy 49(4): 455-460.

Janz NK et Becker MH (1984) The health belief model: a decade later. Health Education Quarterly 11(1): 1-47.

Laurent D (2009) Mission relative au mouvement consu- mériste en France. Secrétariat d'Etat à l'industrie et à la consommation. Paris: La Documentation Française.

Lewis JD et Weigert A (1985) Trust as a social reality.

Social Forces 63(4): 967-985.

Lichtlé MC et Plichon V (2008) Mieux comprendre la fidélité des consommateurs. Recherche et Applications en Marketing 24(4): 121-141.

Luhmann N (1988) Familiarity, confidence, trust: problems and alternatives. In: Gambetta G (éd.), Trust. New York: Basil Blackwell.

Maillard-Wilhelm M-C (2014) Compréhension du fonc-tionnement de l'appel à la peur et du rôle médiateur de la réactance situationnelle en communication pré-ventive de l'anorexie. Thèse de sciences de gestion: Université de Grenoble.

Mayer RC, Davis JH et Schoorman FD (1995) An inte- grative model of organizational trust. The Academy of Management Review 20(3): 709-734.

McKnight DH, Kacmar CJ et Choudhury V (2004) Dispositional trust and distrust distinctions in pre- dicting high- and low-risk internet expert advice site perception. $E$ Service Journal 3(2): 35-55.

Martin R (1987) Le consommateur abusif. Paris: Dalloz. Meier O et Schier G (2008) Quelles théories et principes d'actions en matière de gouvernance des associations. Revue Management \& Avenir 6(20): 179-198.

Mitchell VW (1999) Consumer perceived risk: conceptualisations and models. European Journal of Marketing 33(1/2): 163-195.

Morgan RM et Hunt SD (1994) The commitment trust theory of relationship marketing. Journal of Marketing 58(3): 20-38.

Morgan F, Schuler DK et Stoltman JJ (1995) A fra- mework for examining the legal status of vulnerable consumers. Journal of Public Policy \& Marketing 14(2): 267-277.

Moorman C, Zaltman G et Deshpandé R (1992) Relationships between providers and users of market research: the dynamics of trust. Journal of Marketing Research 29(3): 314-328.

Nabec L, Chevalier C, Briat E et Roux D (2015) Légitimité et stratégies de légitimation des associa- tions de consommateurs dans le paysage consumériste actuel. Décisions Marketing 78: $63-77$. 
Nunnally JC (1978) Psychometric Theory, 2ème édition.

New York: Mc Graw-Hill.

Pflieger G (2003) Consommateur, client, citoyen : l'usa-ger dans les nouvelles régulations des services de réseaux. Les cas de l'eau, de l'électricité et des télé-communications en France. Thèse d'urbanisme-amé- nagement: Ecole des Ponts, ParisTech.

Preacher KJ et Hayes AF (2004) SPSS and SAS pro- cedures for estimating indirect effects in simple mediation models. Behavior Research Methods, Instruments, and Computers 36(4): $717-731$

Preacher KJ et Hayes AF (2008) Asymptotic and resam- pling strategies for assessing and comparing indi- rect effects in multiple mediator models. Behavior Research Methods 40(3): 879-891.

Rindova VP, Pollock TG et Hayward MLA (2006) Celebrity firms: the social construction of market popularity. Academy of Management Review 31(1): 50-71.

Rossiter J (2002) The COARSE procedure for scale development in marketing. International Journal of Research in Marketing 19(4): 305-335.

Rotter JB (1967) A new scale for the measurement of interpersonal trust. Journal of Personality 35(4): 651-665.

Rotter JB (1971) Generalized expectancies for interper- sonal trust. American Psychologist 26: 443-452.

Rotter JB (1980) Interpersonal trust, trustworthiness, and gullibility. American Psychologist 35: $1-7$

Roux D (2007) Consumer resistance: proposal for an integrative framework. Recherche et Applications en Marketing (EBSCO English Edition) 22(4): 59-79.

Roux D (2012) Au-delà des réclamations : comprendre et gérer les litiges. Décisions Marketing 67: 49-62.

Roux D, Chevalier C et Nabec L (2015) Les parties pre- nantes consuméristes et l'impact de leur dynamique collective pour les entreprises. Décisions Marketing 77: 47-62.

Sabadie W et Capelli S (2009) Quelle légitimité à communiquer pour les candidats à l'élection présidentielle française : le cas de la communication sur l'envi- ronnement en 2007. Revue Française du Marketing 224(4/5): 21-34.

Sinay-Cytermann A (1994) Protection ou surprotection du consommateur ? La Semaine Juridique Edition Générale 48.

Sirieix L et Dubois PL (1999) Vers un modèle qualité-satisfaction intégrant la confiance ? Recherche et Applications en Marketing 14(3): 1-22. 
Smith N et Cooper-Martin E (1997) Ethics and target marketing: the role of product harm and consumer vulnerability. Journal of Marketing 61(3): 1-20.

Smith JB et Barclay DW (1997). The effects of organizational differences and trust on the effectiveness of selling partner relationships. Journal of Marketing 61(1): 3-21.

Suchman MC (1995) Managing legitimacy: strategic and institutional approaches. Academy of Management Review 20(3): 571-610.

Tenenhaus M, Esposito Vinzi V, Chatelin Y et Lauro C (2005) PLS path modeling. Computational Statistics and Data Analysis 48(1): 159-205.

Thiétart RA (2003) Méthodes de recherche en manage- ment, 2ème édition. Paris:Dunod.

Vestergaard A (2014) Mediatized humanitarianism: trust and legitimacy in the age of suspicion. Journal of Business Ethics 120(4): 509-525.

Webster FE (1973) Does business misunderstand consumerism? Harvard Business Review 51(5): 89-97.

Werle C, Balbo L, Ardito G et Vigne G (2010) Prévention de la surconsommation d'alcool au sein des grandes écoles françaises: l'effet boomerang des messages soulignant la vulnérabilité perçue. Journée Internationale du Marketing de la Santé, Lille, novembre. 


\section{Appendix 1. Qualitative study methodology}

Interviews lasted on average 90 minutes and were conducted in the respondents' homes. The final sample of 51 respondents is varied in terms of gender (55\% men, $45 \%$ women), age (31\% aged $20-35,22 \%$ aged $36-50$ and $47 \%$ aged over 50 ), profession (20\% students, $62 \%$ employed and 18\% retired), marital status (33\% single, 55\% married and 12\% divorced), place of residence (92\% in Paris or surrounding region) and knowledge of consumer associations ( $86 \%$ of respondents have knowledge of consumer associations and $24 \%$ have used their services).

\begin{tabular}{|c|c|c|c|c|c|c|c|c|}
\hline Pseudonym & Sex & Age & $\begin{array}{l}\text { Marital } \\
\text { status }\end{array}$ & Profession & $\begin{array}{l}\text { Place of } \\
\text { residence }\end{array}$ & $\begin{array}{l}\text { Knowledge of } \\
\text { associations }\end{array}$ & $\begin{array}{l}\text { Sought help } \\
\text { with dispute }\end{array}$ & Member \\
\hline Aurore & $\mathrm{F}$ & 20 & Single & Apprentice engineer & $92^{\mathrm{a}}$ & Yes & No & No \\
\hline Manon & $\mathrm{F}$ & 20 & Single & Student & Paris & Yes & No & No \\
\hline Clara & $\mathrm{F}$ & 20 & Single & Student & 75 & Yes & No & Yes \\
\hline Juliette & $\mathrm{F}$ & 21 & Single & Student & $\mathrm{IdF}^{\mathrm{a}}$ & Yes & No & No \\
\hline Fleur & $\mathrm{F}$ & 22 & Single & Student & IdF & Yes & No & No \\
\hline Claire & $\mathrm{F}$ & 23 & Single & Student & 78 & Yes & No & No \\
\hline Clarisse & $\mathrm{F}$ & 27 & Single & Organizer & IdF & Yes & Yes & Yes \\
\hline Alice & $\mathrm{F}$ & 34 & Married & Railway ticket inspector & IdF & Yes & Yes & No \\
\hline Caroline & $\mathrm{F}$ & 38 & Married & Social worker & 92 & Yes & No & No \\
\hline Béatrice & $\mathrm{F}$ & 44 & Married & Dance instructor & Nantes & Yes & No & No \\
\hline Nathalie & $\mathrm{F}$ & 44 & Married & Marketing employee & 92 & Yes & Yes & No \\
\hline Cécile D. & $\mathrm{F}$ & 48 & Married & Housewife & 78 & Yes & No & No \\
\hline Mireille & $\mathrm{F}$ & 50 & Married & $\begin{array}{l}\text { Municipal administrative } \\
\text { employee }\end{array}$ & 91 & Yes & No & No \\
\hline Cécile F. & $\mathrm{F}$ & 52 & Divorced & IT expert & 78 & Yes & No & No \\
\hline Marie & $\mathrm{F}$ & 53 & Married & Civil servant & IdF & Yes & No & No \\
\hline Florence & $\mathrm{F}$ & 53 & Married & Civil servant & Guadeloupe & Yes & Yes & Yes \\
\hline Léa & $\mathrm{F}$ & 53 & Married & Housewife & 78 & Yes & No & No \\
\hline Christine & $\mathrm{F}$ & 53 & Married & Childcare assistant & 91 & Yes & Yes & No \\
\hline Aline & $\mathrm{F}$ & 55 & Divorced & Employee & Paris & Yes & No & No \\
\hline Denise & $\mathrm{F}$ & 55 & Married & Managerial secretary & $\mathrm{IdF}$ & Yes & No & No \\
\hline Michèle & $\mathrm{F}$ & 57 & Married & Retired & IdF & No & No & No \\
\hline Monique & $\mathrm{F}$ & 59 & Divorced & Retired & Paris & Yes & No & No \\
\hline Hélène & $\mathrm{F}$ & 61 & Married & Retired & 78 & Yes & No & No \\
\hline Mathilde & $\mathrm{F}$ & 62 & Married & Nurse & 76 & No & No & No \\
\hline Jules & M & 19 & Single & Employee & 94 & No & No & No \\
\hline Raphaël & $M$ & 19 & Single & Student & 91 & No & No & No \\
\hline Roméo & $M$ & 20 & Single & Teacher & IdF & No & No & No \\
\hline Edouard & $M$ & 21 & Single & Unemployed & 77 & No & No & No \\
\hline Vincent & $M$ & 26 & Single & Student & Paris & Yes & No & No \\
\hline Maxime & $M$ & 26 & Single & Sales manager & 92 & Yes & No & No \\
\hline Thierry & $M$ & 26 & Single & Administrative worker & IdF & Yes & Yes & Yes \\
\hline Pierre & $M$ & 27 & Single & Engineer & 91 & Yes & No & No \\
\hline Jérémy & $M$ & 38 & Married & Sales director & 92 & Yes & No & No \\
\hline Marc & $M$ & 45 & Married & Manager & Nantes & Yes & No & No \\
\hline Baptiste & $M$ & 48 & Married & Senior manager & 94 & Yes & No & No \\
\hline
\end{tabular}


Appendix I (Continued)

\begin{tabular}{|c|c|c|c|c|c|c|c|c|}
\hline Pseudonym & Sex & Age & $\begin{array}{l}\text { Marital } \\
\text { status }\end{array}$ & Profession & $\begin{array}{l}\text { Place of } \\
\text { residence }\end{array}$ & $\begin{array}{l}\text { Knowledge of } \\
\text { associations }\end{array}$ & $\begin{array}{l}\text { Sought help } \\
\text { with dispute }\end{array}$ & Member \\
\hline Louis & $M$ & 50 & Single & Senior manager & Paris & Yes & No & No \\
\hline Michel & M & 50 & Married & Senior manager & 91 & Yes & No & No \\
\hline Frédéric & M & 51 & Married & Estate agent & 91 & Yes & Yes & No \\
\hline Martin & M & 52 & Married & Financial director & 78 & Yes & No & No \\
\hline Antoine & M & 52 & Married & Driving instructor & 91 & Yes & Yes & Yes \\
\hline Stéphane & M & 52 & Married & Senior manager & Paris & Yes & No & No \\
\hline Léo & M & 55 & Divorced & $\begin{array}{l}\text { Senior technical } \\
\text { manager }\end{array}$ & 91 & Yes & No & Yes \\
\hline Alain & M & 55 & Married & Architect & 92 & Yes & No & No \\
\hline André & M & 61 & Married & Retired & Paris & Yes & Yes & No \\
\hline Léon & M & 62 & Married & Presenter & 94 & No & No & No \\
\hline Paul & M & 65 & Married & Retired & 94 & Yes & Yes & Yes \\
\hline Matthias & M & 67 & Single & German teacher & Paris & Yes & No & No \\
\hline Albert & M & 72 & Divorced & $\begin{array}{l}\text { Retired (former business } \\
\text { school professor) }\end{array}$ & 93 & Yes & No & No \\
\hline Jean & M & 74 & Divorced & $\begin{array}{l}\text { Retired (former } \\
\text { university professor) }\end{array}$ & 92 & Yes & Yes & Yes \\
\hline Laurent & M & 75 & Married & $\begin{array}{l}\text { Retired (former HR } \\
\text { role with RATP) }\end{array}$ & 91 & Yes & Yes & $\begin{array}{l}\text { Ex- } \\
\text { member }\end{array}$ \\
\hline Daniel & M & 78 & Married & Retired & 91 & Yes & No & No \\
\hline
\end{tabular}

* The 2-digit figures represent the French departments in which the respondents live; $\mathrm{IdF}=$ Ile de France (Paris region). 